\title{
Exploration of Transnational Merger and Acquisition Decision Based on Risk Control
}

\author{
Yujun Zhong \\ School of Economics and Management, Chongqing Jiaotong University, Chongqing 400074, China \\ Email: idnot4@icloud.com
}

\begin{abstract}
In order to guard against the risks that enterprises will encounter in transnational merger and acquisition, starting with the theory and reality of global enterprise transnational merger and acquisition, the motivation of Chinese enterprises' transnational merger and acquisition is revealed. In addition, various links of risk factors in the process of transnational merger and acquisition are analyzed, and the main risks faced by Chinese enterprises in transnational merger and acquisition are identified. Finally, the risk control and prevention methods suitable for enterprises are put forward, so as to provide reference for Chinese enterprises to prevent merger and acquisition risks.
\end{abstract}

Keywords: Transnational merger and acquisition, risk factor, risk control.

\section{Introduction}

Western developed countries have developed a large number of large scale enterprises through merger and acquisition and controlled a large number of market share worldwide. With the development of economic globalization and China's entry into the World Trade Organization, Chinese enterprises will face fierce competition from transnational enterprises (Leng and Zhao, 2013). At the same time, many enterprises have established the goal of international development, expecting to expand overseas. On the macro level, it is very important for our economy to expand the scale of enterprises and create a large number of large-scale enterprises to participate in international competition. On the micro level, the development of enterprise merger and acquisition market can make full use of the flexibility of market allocation of resources to achieve the survival of the fittest and optimize the industrial structure (Moschieri, Ragozzino and Campa, 2014).

Based on the theories and methods of economics, management, financial engineering, option theory and game theory, the driving wheel model of transnational merger and acquisition is constructed from the basic connotation, practical significance and related theories of transnational merger and acquisition. The main management activities of transnational merger and acquisition, namely, decision-making, operation and risk control, are studied and discussed, respectively. Finally, a set of strategic decisions suitable for enterprise development is obtained, which provides reference for other enterprises' risk control of transnational merger and acquisition.

\section{$2 \quad$ State of the Art}

In view of the rapid development of transnational merger and acquisition on the global scale, it is urgent to guide the new phenomena and new problems in the field of transnational merger and acquisition in the theoretical explanation and practice (Chen and $\mathrm{Xu}, 2014$ ). The transaction cost theory, contract theory, incentive theory, principal-agent theory, property right theory, asymmetric information theory, incomplete information theory and game theory have made great progress in the past 10 years, making the theory of transnational merger and acquisition progress very rapid, which has become one of the most active fields in western economics at present (Min, Boateng and Newton, 2016). However, the study of transnational merger and acquisition by foreign experts and scholars is mainly based on the developed countries, such as the United States, the EU countries and Japan, to explain the motivation of the transnational merger and acquisition of enterprises in developed countries (Basuil and Datta, 
2015). It can be seen that in this field, the theoretical hypothesis is widespread. In terms of the origin and development of the theoretical evolution, the existing theories of transnational merger and acquisition can be divided into 3 categories. The first category is the related theories of Marx and Lenin, including Marx's capital concentration theory and Lenin's capital output theory (Bernardis and Giustiniano, 2015). The second category is the theory of merger and acquisition, which is popular in the west at present, that is, the theory of transnational merger and acquisition and pure domestic merger and acquisition, such as the scale economy theory, transaction cost theory, market power theory, manager stratum expansion motivation theory, financial synergy effect, stock speculation theory and so on (Huang, Jiang, Lie and Yang, 2014). Its branch also includes efficiency theory, information and signal theory, agency problem, management theory, arrogant hypothesis, free cash flow hypothesis, market force theory, tax effect theory and redistribution improvement value theory (Bauer and Matzler, 2014). The third category is the transnational direct investment theory, such as monopoly advantage theory, internalization theory, international product cycle theory, location factor theory, international production comprehensive theory, oligopoly reaction theory, and transnational enterprise theory, growth oriented theory, use import theory, expanded unique advantage theory, defense theory, customer following theory and favorable opportunity theory (Barraclough, Robinson, Smith, and Whaley, 2013).

\section{Theory}

In general, five important factors should be taken into account in merger and acquisition decisionmaking, including the self-assessment of the company, the analysis of the basic situation of the alternative target, the analysis of the basis for the merger and acquisition, the analysis of the possibility of merger and acquisition, and the economic and social benefit evaluation of the merger and acquisition. However, the transnational merger and acquisition is actually the result of the foreign direct investment wheel and the merger and acquisition wheel, which is the integration of the two. The decision of transnational merger and acquisition generally includes two closely-related decisions: the foreign direct investment decision and the merger and acquisition decision. On the basis of the analysis of the internal and external environment of the investment, the foreign direct investment decision mainly determines the location of the transnational merger and acquisition investment (Liu and Woywode, 2013); the merger and acquisition decision mainly aims at the choice of the target and the timing of the merger, as shown in Figure 1.

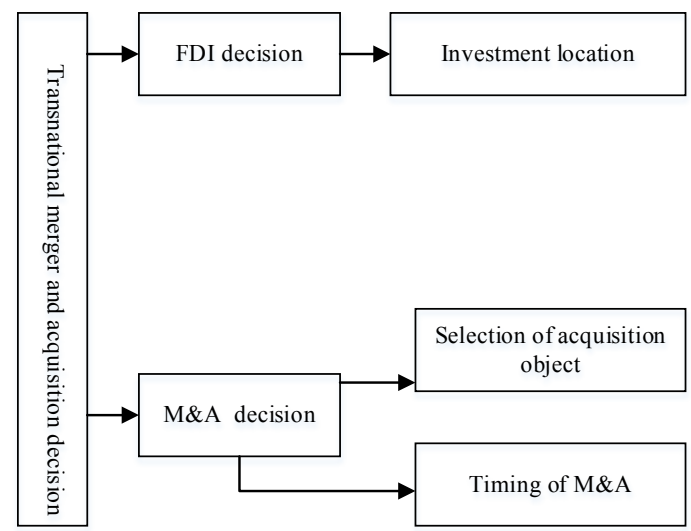

Figure 1. Transnational merger and acquisition decision

The foreign direct investment wheel mainly answers the question of why the enterprise needs to cross the national boundary for direct investment, that is, the driving force of the enterprise foreign direct investment; and the merger and acquisition wheel mainly answers the choice of the investment mode, mainly the choice of the construction and the merger and acquisition. The driving wheel model of transnational merger and acquisition is shown in Figure 2. 


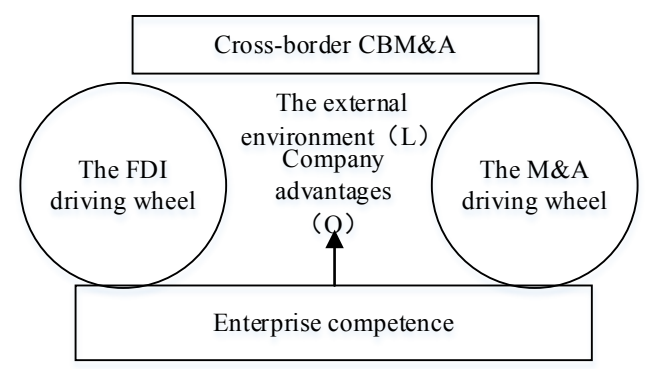

Figure 2. The driving wheel model of cross-border M\&A

\subsection{Core Competence and Transnational Merger and Acquisition}

Merger and acquisition is an important investment way for enterprises to achieve rapid external growth. Transnational merger and acquisition is a strategic behavior. It is closely related to the global management strategy of transnational enterprises. The global multinationals implemented the diversification strategy from 1950s to 1980s, and began to implement the refocusing strategy in 1990s (Szücs, 2014). In the early twenty-first Century, refocusing will become the leading strategy of the multinational companies. This new strategy emphasizes the cultivation, maintenance and development of core competence (some translated as core competitiveness). On this basis, the company's business is brought to the most competitive industries, and the focus of its management is placed on the most advantageous link of the core industry value chain, and the non-core business is outsourced. Therefore, transnational corporations must first understand core competence correctly for merger and acquisition.

The core competence and external performance of the enterprise:

Core competence originally appears as a kind of enterprise theory. It mainly focuses on the analysis of the characteristics of enterprises with competitive advantages in the industry. The definition of core competence was proposed by Prahalad and Hamel in 1990 in "Core Competence of a Company" published in the Harvard Business Review. They argue that "core competence is the accumulation of knowledge in an organization, especially how to coordinate different production skills and organically integrate the knowledge of multiple technical schools".

The core competence is a special kind of resources and ability that the enterprise has, which can make the enterprise lead and advantage in the fierce market competition, thus can bring the profit to the enterprise higher than the average profit level of the same industry. "If a particular kind of resource and ability is controlled by a large number of competitive enterprises, then this kind of resource cannot be the source of competitive advantage for any enterprise" (Ca, Kim, Park and White, 2015). But this ability refers to the ability combination or ability system peculiar to an enterprise rather than a technology or skill that is owned. At the same time, the core competence is generally the result of an enterprise's long-term accumulation, which can reflect the characteristics of the enterprise and distinguish it from other enterprises.

Transnational merger and acquisition and core competence strategy:

The research on enterprise competition strategy is roughly divided into two major groups: the environmental school, represented by Michael Porter, focuses on the analysis of the impact of the industrial environment on the competitiveness of enterprises. Porter believes that the success of an enterprise comes from two aspects: the attractiveness of the industry in which the enterprise is located and the relative position of the enterprise in the industry. The profitability of enterprises can be divided into two aspects: industrial effect and market position. Industrial structure and relative position are important concepts of enterprise strategy. The function of industrial structure is to explain the sustainability of profit, and the difference of profit depends on the relative market position of enterprises. The choice of scope is the central issue of enterprise strategy. The resource dependence school, represented by American scholar Jay Barney, believes that a complete understanding of the source of competitive advantage in environmental analysis needs to be added with the analysis of the internal strength and weakness of the enterprise. The resource dependence school pays attention to analyzing 
why enterprises pursue strategies with different outputs according to their internal characteristics. Organizations adopt different ways of development and enterprises have different resources, so enterprises adopt different strategies to develop their different resources.

Judgment and construction of core competence in transnational merger and acquisition:

In 1991, Grant proposed that enterprises should determine its core competence based on the following four characteristics: appropriability, durability, transferability, and replicability.

The cultivation and development of core competitiveness is achieved through the reorganization and accumulation of enterprises at all levels. The core status of the core competitiveness in the competitive advantage of the enterprise also makes it the core of the reorganization of the enterprise naturally. And those enterprises that can accomplish this work in the shortest time will undoubtedly gain a favorable market position. For example, in order to master the leading position in flat screen display technology, SHARP and Toshiba Company have started to invest heavily in the research and development of the technology in the 10 years before the market showed a decent profit prospect. When the United States competitors noticed the huge profit potential of the market, they had lagged far behind their Japanese competitors. SHARP and Toshiba Company products account for almost $90 \%$ of the market share. Therefore, it is the core of this stage to acquire or establish competitive factors such as key technical expertise that constitutes core competitiveness.

There are two ways to cultivate core competitiveness of enterprises: internal training or external construction. It is relatively slow to establish core competitiveness through internal development because it is constrained by the internal resources of enterprises and bound by traditional concepts. By absorbing "external" resources such as mergers and acquisitions, the necessary core competitiveness elements can be acquired in a relatively short period of time.

One of the important reasons for transnational merger and acquisition is to build, extend and strengthen their own core competence in a fairly short period of time through merger and acquisition. Practice proved that transnational merger and acquisition strategy based on core competence had become the dominant strategy of transnational corporations. However, the core competence of enterprises must be dynamically adapted to the behavior of merger and acquisition. On the one hand, the core competence of the enterprise promotes the occurrence of merger and acquisition. On the other hand, the merger and acquisition behavior further promotes the construction, extension and strengthening of the core competence of the enterprise. After transnational corporations carry out transnational merger and acquisition, the core competence of enterprises must be maintained and strengthened dynamically when the internal and external environment of the enterprise changes greatly, so as to maintain the sustainability of the enterprise expansion benefit and the effectiveness of the enterprise expansion behavior.

\subsection{Foreign Direct Investment Decision-Making Method of Transnational Merger and} Acquisition

Under the premise of defining its core competence and development strategy, the core content of foreign direct investment decision for transnational merger and acquisition is to determine the location of transnational merger and acquisition investment on the basis of the analysis of investment environment.

The international investment environment refers to, within a certain period of time, the organic whole that the influence of the host country (region) and the factors that determine the entry of the international direct investment and the expected economic benefits. It is the external condition and the prerequisite for carrying out the activities of international direct investment. Because international direct investment is a kind of transnational investment, there are differences in the political, social, economic, cultural and legal aspects of the country. Before making the investment decision, investors should compare the investment environment of the host country, so as to determine the countries and regions with high safety and profit as the location of the foreign direct investment. If the investment location lacks the necessary elements for the survival and development of capital, that is, the lack of material, technical, social and economic conditions, then an investment project will be rejected in the feasibility demonstration. Even if the investment decision is barely made, it will encounter all kinds of difficulties in the construction process and the production and operation activities, leading to the failure of the expected investment effect. Therefore, transnational corporations and enterprises are directly faced with the huge risk of investment failure. For the companies engaged in international direct 
investment, it is necessary to investigate and evaluate the factors of the host country's investment environment through various approaches and appropriate ways, and to optimize the investment places to determine the places with the best investment environment and make the right investment decisions.

The core of transnational merger and acquisition decision is to determine suitable investment location on the basis of careful analysis and evaluation of investment environment. The determination of the location of transnational merger and acquisition investment involves the comparison, analysis and evaluation of multiple factors. At present, the commonly used methods are multi factor scoring analysis method, key factor assessment method, cold and hot comparison method, Dow Chemical Company assessment method, sampling evaluation method, similarity evaluation method, and international risk rating method. There are similarities of different ways in essence, which can be said to be the embodiment of analytic hierarchy process (AHP).

The AHP was first proposed by American operational research scientist and Professor T.L.Saaty of University of Pittsburgh in the early 1970s. Since 1980s, it has been greatly developed and applied. It is a simple method for quantitative analysis of non-quantitative events in the system engineering. It is also effective method for the description of the subjective judgment of people. This method can be used to determine the weights of each factor in multifactor analysis and decision analysis.

The hierarchical structure model, based on the analysis of the elements and the relationships of the problems, divides the elements into groups according to their properties. The elements of the same level, as a criterion, play a dominant role in some elements of the next level, and they are also dominated by the upper elements. Allocation can be carried out to facilitate comparison between elements. When there are more elements (such as more than 9) at a certain level, the level can be further divided into several levels, and this top-down domination relationship forms a hierarchical structure. At the highest level, there is usually only one element, called the target layer: some intermediate layers are usually referred to as the criterion levels, and the lowest level is commonly referred to as the scheme level.

The hierarchical structure for the determination of the location of transnational merger and acquisition investment is shown in Figure 3.

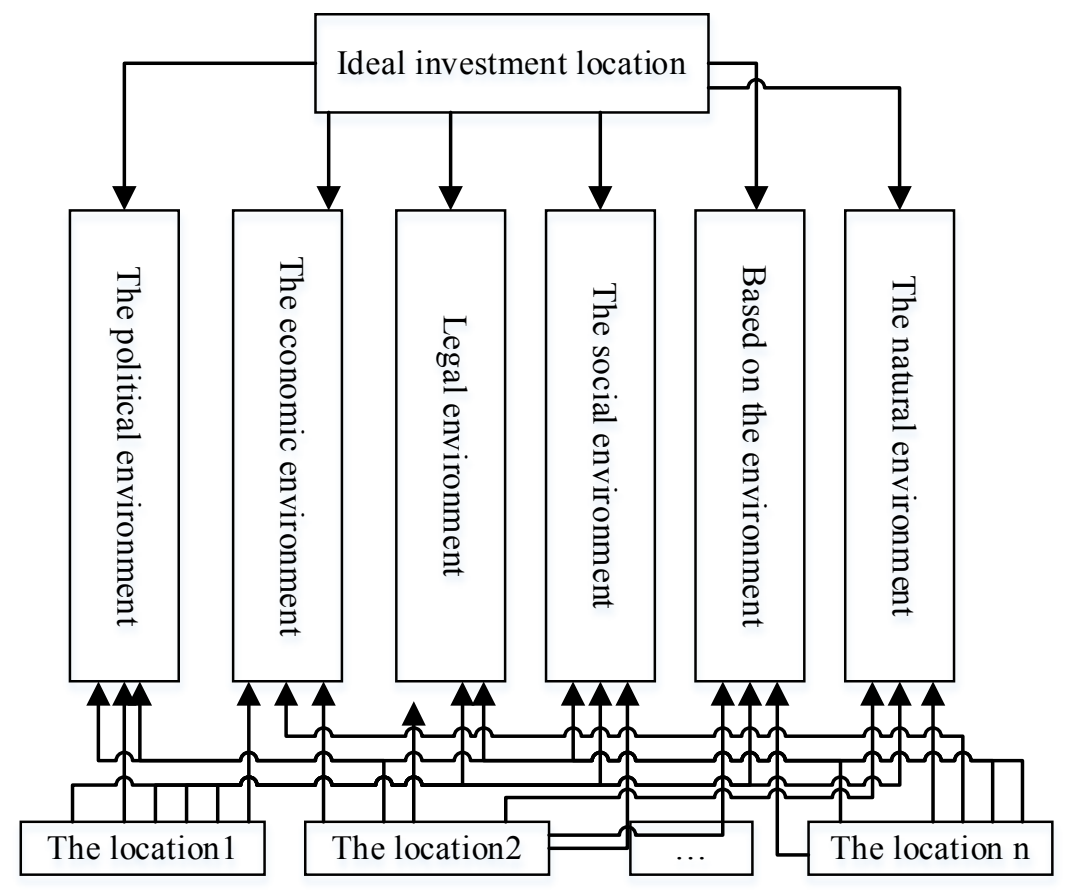

Figure 3. The hierarchical structure of the location of cross-border M\&A investment

\subsection{Decision-Making Method for Transnational Merger and Acquisition}

The core content of decision of transnational merger and acquisition is to determine whether and when 
merger and acquisition should be chosen after the transnational companies have defined their own core competence and development strategy and determined the specific location of investment.

Affected by the complex factors such as the cost of precipitation, the market competition and the opportunity for growth, the decision-making information of transnational merger and acquisition has great incompleteness. Therefore, transnational merger and acquisition, as a modern investment method, has strong uncertainty. To make the merger and acquisition successful, the transnational companies must have strong flexibility. From the study of merger and acquisition, it is considered that the flexibility of merger and acquisition refers to the least (effective) opportunity cost decision-making or disposal ability for transnational companies to face uncertainties of external environment in the process of transnational merger and acquisition. In the process of merger and acquisition decision, the merger and acquisition enterprises often face the choice of decision time, the value evaluation and selection of Target Corp, the financing way and the integration after the merger and acquisition. Each process is the result of the choice of opportunities, that is, the decision problem of Simon. The physical option method is the efficient solution to the decision with strong uncertainty.

Backgwheel of physical option:

Investment refers to the payment of funds or funds that can bring benefits to investors in a certain period of time. From this point of view, investment can be divided into physical (project) investment and financial investment. The former is related to physical assets, such as land, equipment, plant and so on, while the latter is inseparable from financial assets, such as stocks, bonds, options, futures and currencies. For a long time, the basic method of evaluating physical investment is the discounted cash flow method (referred to as DCF). It provides the basis for quantitative analysis of physical investment decisions. But it implies two unrealistic assumptions: the decision of the enterprise cannot be delayed and it can only choose to invest or not to invest, while the project does not make any adjustments in the future. It is these assumptions that make the DCF method ignore many important realistic factors (such as uncertainty of future investment projects and information asymmetry) in the evaluation of physical investment. Therefore, in the evaluation of project investment decisions with operational flexibility or strategic growth, the value of these projects will be underestimated and even lead to wrong decision making. In view of the shortcomings of the DCF method, some scholars and businessmen put forward a more practical method - physical option method.

Classification of physical options:

According to the specific situation of the investment project, some scholars classify physical options. Myers, McGuigan and Rrcthow believe that physical options have the following forms: the investment option is also called the option of waiting for investment, the option of cancellation of projects, the end option and the growth option. Trigeorgis divides the physical options into the starting or expanding option, abandoning and tightening option, and waiting for or slowing down or accelerating development option; Dixit and Pinkdyck divide physical options from the perspective of the enterprise as: delayed option, time cumulative option, production scale change option, abandonment option, convertible option, growth option and interactive option, and analyze them.

Further development of merger and acquisition investment decision:

In the process of actual investment decision, the physical option method is improved compared with the net present value method, but the decision of transnational merger and acquisition is not a decisionmaking behavior controlled by a transnational company. It is influenced by the strategy of other merger and acquisition companies at the same time, and it is a reaction to its strategic behavior. The use of physical option can be more effective in the value of various opportunities that are included in the investment decision. However, one of the most obvious deficiencies in this approach is that it does not take into account the behavior or reaction of competitors. Therefore, foreign and domestic scholars have begun to study the theory and method of option game.

\section{Discussion}

The decision of transnational merger and acquisition is the results driven by the foreign direct investment wheel and the merger and acquisition wheel, which is the integration of the two. Generally, it includes two closely related decisions: foreign direct investment decision and merger and acquisition decision. Foreign direct investment decision, on the basis of the internal and external environment of 
investment, determines the advantage and location of the enterprise of transnational merger and acquisition investment; merger and acquisition decision mainly carries on the target object choice as well as the merger opportunity choice.

The global transnational companies carried out the diversification strategy from 1950s to 1980s, and began to implement the refocusing strategy in 1990s. The refocusing in the beginning of $21^{\text {st }}$ Century will become the leading strategy of the transnational companies. The relationship between core competence and transnational merger and acquisition is firstly discussed. It is believed that transnational merger and acquisition should first of all clearly define the core competence and development strategy of the enterprise and clear the investment location. AHP and the target fuzzy evaluation model are considered to be the effective methods for transnational companies to make foreign direct investment decision, so as to determine the location of the transnational merger and acquisition investment.

It is a brand-new practice for Chinese enterprises to conduct transnational operations through transnational merger and acquisition. Its rise and development is the result of China's reform and opening up and its participation in the process of world economic integration. In 2004, some people called it the first year of merger and acquisition of Chinese enterprises. In this year, the number of transnational merger and acquisition incidents of Chinese enterprises increased, and the amount of money was very large. It can be called the first wheel of large-scale transnational merger and acquisition climax of Chinese enterprises. Among them, especially in the case of Lenovo's huge acquisition of IBM personal computer business, Shanghai Automobile Industry Group's acquisition of Korea Shuanglong Automobile Company and other events deserve the most attention and research.

The further development of this practice depends not only on the competitiveness of the enterprises themselves in the world, the development strategy and the management level, but also on the further deepening of the reform of the domestic economic system and the further expansion of the opening-up to the outside world. As a result, Chinese enterprises can better implement the global market operation strategy in the overseas market.

The decision of transnational merger and acquisition is influenced by factors such as the cost of precipitation, the situation of competition and the opportunity for growth in addition to the strategic level and the analysis of the investment environment of the investors. As a modern investment way, transnational merger and acquisition, because of its highly miscellaneous investment environment, makes merger and acquisition investment have strong uncertainty. In order to make merger and acquisition succeed, enterprises must have strong flexible ability. In order to improve the flexible ability of transnational merger and acquisition decision, the physical option method is applied to study the value evaluation and selection problem, the financing mode and the integration of Target Corp after the merger and acquisition. A more in-depth study of the timing of transnational (horizontal) merger and acquisition decision-making is made. The merger and acquisition investment opportunities owned by transnational companies are regarded as the call options held by transnational companies. The value of the merger and acquisition option is analyzed by using the option pricing theory and the critical value of the optimal merger and acquisition investment decision is obtained. It has a certain reference value and practical significance for transnational corporations to carry out transnational merger and acquisition.

\section{Conclusion}

With the development of economic globalization, the deepening of the international financial crisis and the promotion of the "going out" strategy of the Chinese government, the pace of transnational merger and acquisition of Chinese enterprises is speeding up. Transnational merger and acquisition brings great benefits to Chinese enterprises, and at the same time, the risk of loss becomes increasingly prominent. Transnational merger and acquisition has the characteristics of strategic management, project management, financial management and corporate governance. It covers a wide range and many factors, and the inconsistent evaluation standards are beyond the scope of the traditional enterprise project risk assessment method. In particular, the international evaluation of transnational merger and acquisition risk does not form the recognized index framework, evaluation criteria and decision-making basis. As a result, it makes the evaluation of transnational merger and acquisition risk more subjective and onesided. Therefore, it is a practical problem faced by the government, enterprises and scholars at home 
and abroad how to combine the current situation of transnational merger and acquisition of enterprises to formulate a scientific and reasonable risk index evaluation system and decision-making model and guide the practice of transnational merger and acquisition investment.

\section{References}

1. Leng, J., \& Zhao, P. (2013). Study on the impact of the quality of internal control on the performance of m\&a. Journal of Service Science \& Management, 06(3), 223-231. doi: 10.4236/jssm.2013.63025

2. Moschieri, C., Ragozzino, R., \& Campa, J. M. (2014). Does regional integration change the effects of countrylevel institutional barriers on m\&a? the case of the european union. Management International Review, 54(6), 853-877. doi:10.1007/s11575-014-0206-7

3. Chen, F., \& Xu, Y. (2014). Democratization in the host country and institutional risk of cross-border m\&a: an empirical study on chinese listed enterprises. Quality \& Quantity, 48(2), 1013-1025. doi:10.1007/s11135-012-98220

4. Min, D., Boateng, A., \& Newton, D. (2016). The impact of state ownership, formal institutions and resource seeking on acquirers' returns of chinese m\&a. Review of Quantitative Finance \& Accounting, 47(1), 159-178. doi:10.1007/s11156-015-0498-0

5. Basuil, D. A., \& Datta, D. K. (2015). Effects of industry- and region-specific acquisition experience on value creation in cross-border acquisitions: the moderating role of cultural similarity. Journal of Management Studies, 52(6), 766-795. doi:10.1111/joms.12128

6. Bernardis, L. D., \& Giustiniano, L. (2015). Evolution of multiple organisational identities after an m\&a event. Journal of Organizational Change Management, 28(3), 333-355. doi:10.1108/jocm-05-2014-0096

7. Huang, Q., Jiang, F., Lie, E., \& Yang, K. (2014). The role of investment banker directors in m\&a . Social Science Electronic Publishing, 112(2), págs. 269-286. doi:10.2139/ssrn.1787086

8. Bauer, F., \& Matzler, K. (2014). Antecedents of m\&a success: the role of strategic complementarity, cultural fit, and degree and speed of integration. Strategic Management Journal, 35(2), 269-291. doi:10.1002/smj.2091

9. Barraclough, K., Robinson, D. T., Smith, T., \& Whaley, R. E. (2013). Using option prices to infer overpayments and synergies in m\&a transactions. Review of Financial Studies, 26(3), 695-722. doi:10.2139/ssrn.1942231

10. Liu, Y., \& Woywode, M. (2013). Light-touch integration of chinese cross-border m\&a: the influences of culture and absorptive capacity. Thunderbird International Business Review, 55(4), 469-483. doi:10.1002/tie.21557

11. Szücs, F. (2014). M\&a and r\&d: asymmetric effects on acquirers and targets?. Research Policy, 43(7), 1264-1273. doi:10.2139/ssrn.2009415

12. Cai, Y., Kim, Y., Park, J. C., \& White, H. D. (2015). Common auditors in m\&a transactions. Social Science Electronic Publishing, 61(1), 77-99. doi:10.2139/ssrn.2553987 